\title{
Productivity growth, technical change and efficiency change of the Malaysian cage fish farming: an application of Malmquist Productivity Index approach
}

\begin{abstract}
The demand for animal protein especially fish is expanding due to the population growth, increased incomes and changes in eating habits and life styles. The capture fisheries in Malaysia which supply over $70 \%$ of the fish used for food are over-exploited, and the yield has become stagnant over the last decades and in some cases it has even declined. In addition, the balance of trade for the past decade has been negative signaling a threat to the economic growth. However, aquaculture has the potential to meet these challenges if it is well practiced. This can be done through improving productivity of fish farms. The study aims to compute the total factor productivity (TFP) growth and its components. In addition, it aims to identify the sources of TFP growth in aquaculture. Malmquist Productivity Index using data envelopment analysis and regression model has been employed to analyze the data. The TFP growth was estimated to be greater than one, indicating progress in the productivity. According to the results obtained in this study, technological change is the more important contributor to TFP growth. Nevertheless, efficiency changes also play a vital role in improving aquaculture production.
\end{abstract}

Keyword: Cage fish farming; Malmquist Productivity Index; Data envelopment analysis; Total factor productivity; Aquaculture 